\title{
Ablation observations for 2008-2011 from the Programme for Monitoring of the Greenland Ice Sheet (PROMICE)
}

\author{
Robert S. Fausto, Dirk van As and the PROMICE project team*
}

Recent estimates from the glaciological community agree that the Greenland ice sheet is losing mass at an accelerated pace due to climate change (Velicogna 2009; Khan et al. 2010; Rignot et al. 2011). This has caught the attention of the public and policy makers due to the potential impact on sea-level rise (Dahl-Jensen et al. 2009). The mass loss can be attributed approximately equally to increases in meltwater runoff from surface melt and iceberg production (van den Broeke et al. 2009).

The robustness of mass-balance predictions relies heavily on observational data from the Greenland ice sheet and in recent years the need for frequent, reliable surface mass-balance measurements has increased (IPCC 2007; Dahl-Jensen et al. 2009). In anticipation of this need, the Programme for Monitoring of the Greenland Ice Sheet (PROMICE) was initiated in 2007, delivering in situ data from a network of automatic weather stations (AWS) covering eight different regions of the ice sheet (Fig. 1; van As et al. 2011). Apart from the direct insight into the surface mass balance provided by these stations, the in situ data are also valuable for calibrating and validating melt estimates from remote sensors and surface mass-balance models (Dahl-Jensen et al. 2009). In this paper, we present the ablation records for the PROMICE AWSs for 2008-2011, and the impact of the extraordinary atmospheric conditions on ablation in 2010 (Tedesco et al. 2011) are compared to the other years.

\section{PROMICE automatic weather stations}

The PROMICE network in Greenland currently consists of eight sites with two (or three) AWSs placed at different elevations (Fig. 1; Table 1; Ahlstrøm et al. 2008) with a total of 18 stations. At each site, one station is typically located in the lower ablation zone close to the margin and the other in the upper ablation zone. Exceptions are station KAN_U, which is placed in the lower part of the accumulation zone, and sta-

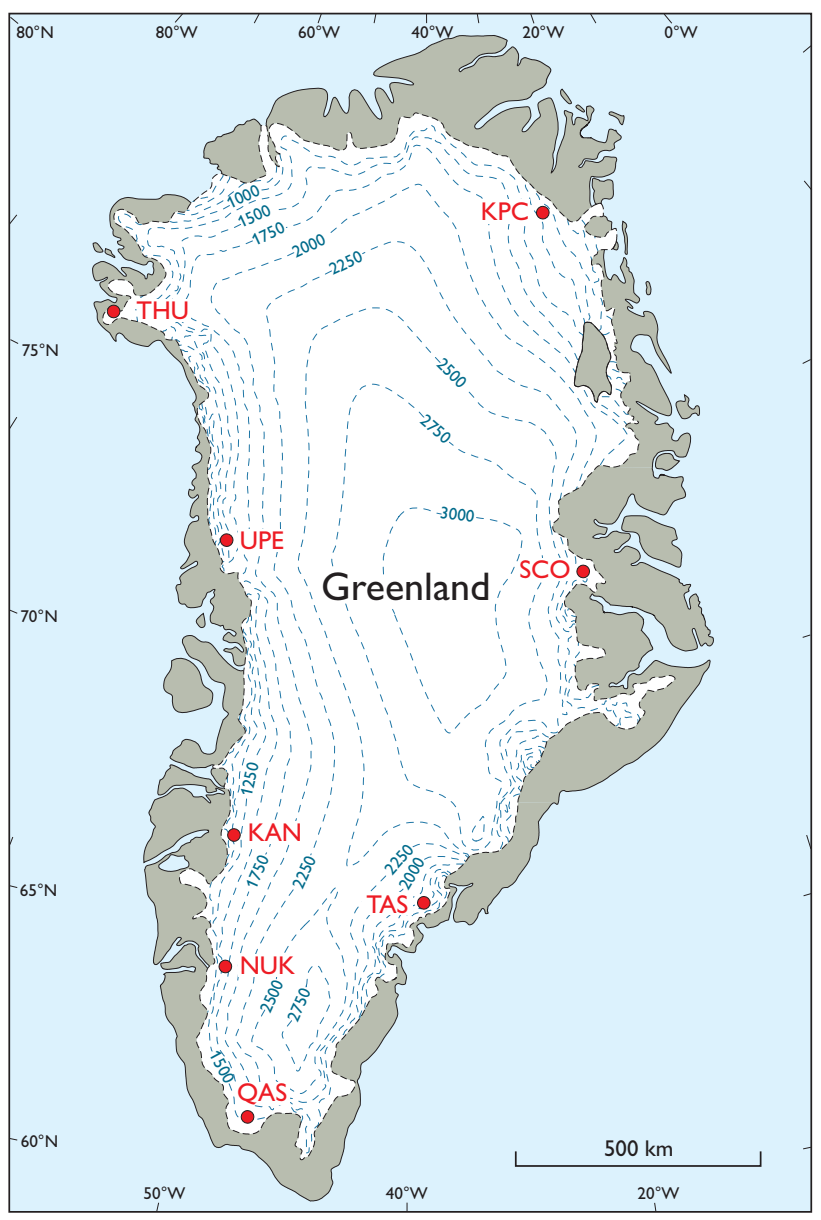

Fig. 1. Map of Greenland showing the locations of the PROMICE automatic weather stations. Each dot represents two or three stations. Station names are found in Table 1. Dashed lines: elevation contours.

tion TAS_U, which is placed well below the equilibrium-line altitude for reasons of accessibility. Each station measures all relevant meteorological parameters and ice and snow ablation (Fig. 2). It measures and stores data every ten minutes

* Andreas P. Ahlstrøm, Signe B. Andersen, Morten L. Andersen, Michele Citterio, Karen Edelvang, Signe H. Larsen, Horst Machguth, Søren Nielsen and Anker Weidick. 
Table 1. PROMICE automatic

weather station metadata (status 2011)

\begin{tabular}{|c|c|c|c|c|}
\hline $\begin{array}{l}\text { Station } \\
\text { name }\end{array}$ & $\begin{array}{l}\text { Latitude } \\
\left({ }^{\circ} \mathrm{N}\right)\end{array}$ & $\begin{array}{l}\text { Longitude } \\
\left({ }^{\circ} \mathrm{W}\right)\end{array}$ & $\begin{array}{c}\text { Elevation } \\
\text { ( } \mathrm{m} \text { a.s.l.) }\end{array}$ & Start date \\
\hline KPC_L* & $79^{\circ} 55^{\prime}$ & $24^{\circ} 05^{\prime}$ & 380 & 17 July 2008 \\
\hline KPC_U & $79^{\circ} 50^{\prime}$ & $25^{\circ} 10^{\prime}$ & 870 & 17 July 2008 \\
\hline SCO_L & $72^{\circ} 14^{\prime}$ & $26^{\circ} 49^{\prime}$ & 470 & 21 July 2008 \\
\hline $\mathrm{SCO}_{-}^{-} \mathrm{U}$ & $72^{\circ} 24^{\prime}$ & $27^{\circ} 15^{\prime}$ & 1000 & 21 July 2008 \\
\hline TAS_L & $65^{\circ} 38^{\prime}$ & $38^{\circ} 54^{\prime}$ & 270 & 23 August 2007 \\
\hline TAS_U & $65^{\circ} 42^{\prime}$ & $38^{\circ} 52^{\prime}$ & 580 & 15 August 2007 \\
\hline QAS_L & $61^{\circ} 02^{\prime}$ & $46^{\circ} 51^{\prime}$ & 310 & 24 August 2007 \\
\hline QAS_U & $61^{\circ} 11^{\prime}$ & $46^{\circ} 49^{\prime}$ & 890 & 7 August 2008 \\
\hline NUK_L & $64^{\circ} 29^{\prime}$ & $49^{\circ} 32^{\prime}$ & 560 & 20 August 2007 \\
\hline NUK_U & $64^{\circ} 30^{\prime}$ & $49^{\circ} 16^{\prime}$ & 1140 & 20 August 2007 \\
\hline NUK_N & $64^{\circ} 57^{\prime}$ & $49^{\circ} 53^{\prime}$ & 930 & 26 July 2010 \\
\hline KAN_L & $67^{\circ} 60^{\prime}$ & $50^{\circ} 70^{\prime}$ & 670 & 1 September 2008 \\
\hline KAN_M & $67^{\circ} 40^{\prime}$ & $48^{\circ} 49^{\prime}$ & 1280 & 1 September 2008 \\
\hline KAN_U & $67^{\circ} 00^{\prime}$ & $47^{\circ} 10^{\prime}$ & 1830 & 4 April 2009 \\
\hline UPE_L & $72^{\circ} 54^{\prime}$ & $54^{\circ} 18^{\prime}$ & 230 & 17 August 2009 \\
\hline UPE_U & $72^{\circ} 53^{\prime}$ & $53^{\circ} 32^{\prime}$ & 980 & 17 August 2009 \\
\hline THŪ_L & $76^{\circ} 24^{\prime}$ & $68^{\circ} 16^{\prime}$ & 570 & 9 August 2010 \\
\hline THU_U & $76^{\circ} 25^{\prime}$ & $68^{\circ} 09^{\prime}$ & 770 & 9 August 2010 \\
\hline
\end{tabular}

*L: Lower station, M: Middle station, U: Upper station, N: New station.

with the exception of the wind-speed observations that give the mean wind speed since the last measurement cycle, and the GPS measurements, which follow the transmission schedule. During winter (day 301 to day 99 of the year) the acquired data are transmitted once a day at midnight to limit power consumption when solar power is not available. During summer (day 100 to day 300) the data are transmitted hourly. The transmissions consist of daily or hourly average values of the more variable quantities such as temperature or radiation. Values of less variable quantities, such as surface height and station tilt are appended once every six hours in summer and once a day in winter for all daily transmissions.

\section{Instrumentation and accuracy}

The PROMICE AWSs are equipped with an Ørum \& Jensen NT1400 pressure transducer assembly and two Campbell Scientific SR50A sonic rangers that monitor surface-height change caused by accumulation and ablation. The pressure transducer assembly consists of a (non-freezing) liquid-filled hose with a pressure transducer located at its end/bottom. The hose is drilled into the ice. The pressure signal registered by the transducer is that of the vertical liquid column over the sensor, which can be scaled to depth using the density of the liquid. The free-standing AWS tripod (Fig. 2) moves down with the ablating surface and the hose melts out of the ice, reducing the hydrostatic pressure from the vertical liquid column in the hose. The reduction in pressure provides the ablation totals. The assembly was first constructed and implemented by Bøggild et al. (2004). Since the first successful

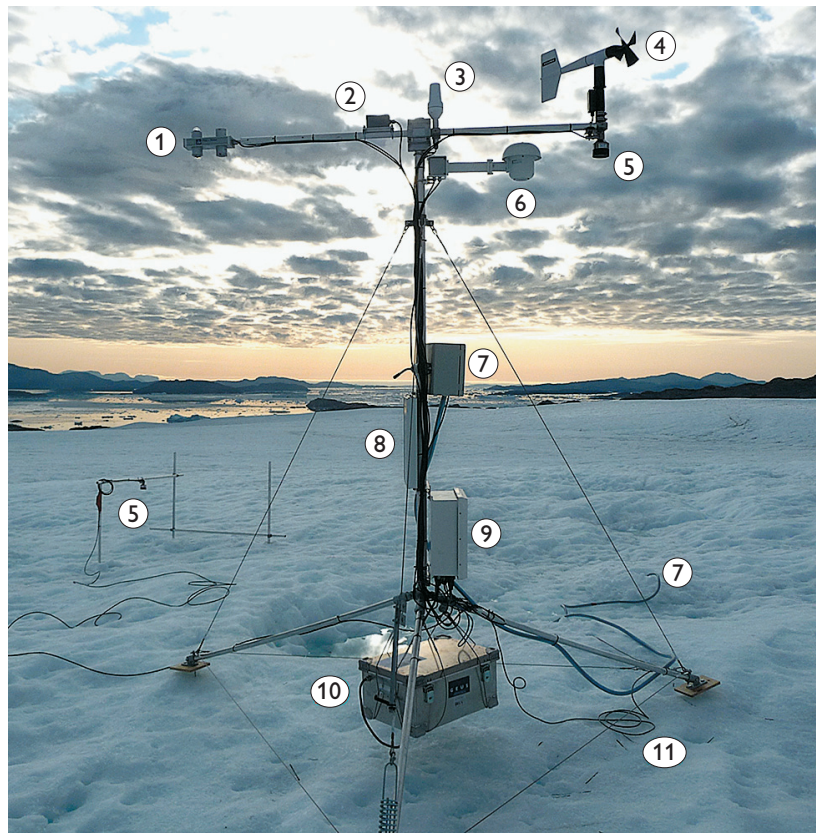

Fig. 2. The PROMICE automatic weather station UPE_L photographed on 17 August 2009. 1: radiometer. 2: inclinometer. 3: satellite antenna. 4: anemometer. 5: sonic rangers. 6: thermometer and hygrometer. 7: pressure transducer. 8: solar panel. 9: data logger, barometer and GPS. 10: battery box with $4 \times 28$ Ah batteries. 11: 8-level thermistor string.

tests in 2001, we have developed the system and now use a larger diameter hose and have changed from relative to absolute pressure transducers. We also use an ethylene-glycol solution, instead of alcohol and secure the upper reference level of the assembly (in the form of a bladder) to the mast instead of leaving it exposed on the ice surface.

By measuring on a (sub-)daily timescale, the pressure transducer assembly is well suited to monitor ice ablation in remote regions, with clear advantages over other well-established methods. For instance, the stake readings providing information about surface-height change are done at every maintenance visit, so the records are limited to the visits. The accuracy of the SR50A sonic ranger is given by the manufacturer (Campbell Scientific) to be $\pm 1 \mathrm{~cm}$ or $\pm 0.4 \%$ of the measuring height after temperature correction. This was confirmed over 2.3 months of a virtually accumulation-free wintertime period at SCO_U, during which time standard deviations of $1.7 \mathrm{~cm}$ and $0.6 \mathrm{~cm}$ were found (after spike removal), corresponding to $0.7 \%$ and $0.6 \%$ of the distance measured by the two sonic rangers, respectively. However, the precision of the readings from these sensors may reduce over time as the sensors degrade due to continuous cycles of moisture freezing on and melting off them. A major problem with sonic rangers in surface-mass balance studies is that they need to be mounted on the stake assemblies drilled into 
the ice. During a single melt season, these stake assemblies can melt out several metres, often causing them to move or even collapse during strong winds. In comparison, the pressure transducer assembly is operational until it has melted out of the ice, which can take several years depending on drill depth and the local ablation rate. This reduces the need for annual station visits, and thereby the considerable expenses associated with logistics in Greenland. The measurement uncertainty of the pressure transducer sensor given by the manufacturer is $2.5 \mathrm{~cm}$. The mean standard deviation of the UPE and SCO pressure transducer readings outside the ablation season is found to be $\pm 1 \mathrm{~cm}$, indicating a small random error comparable to that of the sonic ranger. The precision of the pressure transducer readings falls over time as the transducer degrades due to the continuous pressure on the sensor.

Sensitivity drift defines the amount by which an instrument's sensitivity varies as ambient conditions change. Calibration tests of the pressure transducer show that the sensor sensitivity drift amounts to $1.6 \%$ on average for a four-year measuring period ( $0.4 \%$ per year), suggesting that drift is not a large source of error. The pressure transducer is especially suitable for high ablation areas of $>3 \mathrm{~m}$ per year because it is independent of the stakes drilled into the ice (Fig. 2).

\section{Ablation records for 2008-2011}

The PROMICE ablation records presented in Table 2 are based on measurements by sonic rangers and pressure transducers, supplemented by stake readings. The net ablation values are calculated as the height difference between the end-of-melt-season surface level in the given year and the year before. The geographical distribution and annual net ablation records in Table 2 show that for all station pairs, the lower stations measure larger ablation totals than the upper ones, because the temperature decreases with elevation and the seasonal averaged surface albedo decreases towards the ice margin. There are considerable latitudinal differences as well, as the Greenland ice sheet is more than $2000 \mathrm{~km}$ long. Ablation totals in the southern part of Greenland typically amount to 3-7 $\mathrm{m}$ (at the lower TAS, QAS and NUK stations), whereas ablation totals at the more northerly SCO_L and UPE_L stations only amount to 2-3 $\mathrm{m}$ at low altitudes ( $<500 \mathrm{~m}$ a.s.l.). The ablation totals (negative value is net accumulation) from the upper stations (>500 $\mathrm{m}$ a.s.l.) typically amount to -0.3 to $4 \mathrm{~m}$ in the south (TAS, QAS, NUK, $\mathrm{KAN}$ ) and -0.1 to $3 \mathrm{~m}$ in the north (KPC, SCO, UPE).

The record-warm year 2010 (in most regions of Greenland) showed the largest ablation at most AWS sites, followed by 2008,2011 , and lastly 2009 in the four-year PROMICE record. The 2010 ablation year was characterised by relative-
Table 2. Yearly ablation totals, given as the difference between the surface height at end of the melt season and that of the previous years, in metres snow/ice equivalent per year

\begin{tabular}{|c|c|c|c|c|}
\hline Stationlyear & 2008 & 2009 & 2010 & 2011 \\
\hline KPC L L & _* & $-^{\dagger}$ & ${ }_{-}^{\dagger}$ & ${ }_{-}^{\dagger}$ \\
\hline KPC_U & _* & $-0.1^{\ddagger}$ & $0.1^{\ddagger}$ & $0.2^{\ddagger}$ \\
\hline $\mathrm{SCO}^{-} \mathrm{L}$ & _* & 2.6 & 3.5 & 3.1 \\
\hline SCO_U & _* & 1.4 & 2.5 & 2.1 \\
\hline TAS L & 3.6 & \multicolumn{2}{|c|}{$7.4^{* *}$} & $3.4^{\ddagger}$ \\
\hline TAS_U & 3.3 & $1.5^{\ddagger}$ & $3.9^{\$}$ & 2.9 \\
\hline QAS̄_L & 7.3 & - & 9.3 & 5.5 \\
\hline QAS_U & $-*$ & $-0.3^{\ddagger}$ & 3.4 & 0.8 \\
\hline NUK_L L & 5.3 & 4.8 & 7.2 & - \\
\hline NUK_U & 2.2 & 1.5 & 2.5 & 2.3 \\
\hline $\mathrm{NUK}^{-} \mathrm{N}$ & - & - & -* & 5.1 \\
\hline KAN_L & _* & 3.5 & 5.4 & 4.0 \\
\hline KAN_M & -* & $0.3^{\ddagger}$ & $2.6^{\ddagger}$ & $1.7^{\ddagger}$ \\
\hline KAN_U & - & -* & - & $-0.2^{\ddagger}$ \\
\hline UPE_L & - & _* & 3.2 & 2.9 \\
\hline UPE_U & - & _* & 2.7 & 2.6 \\
\hline THU_L & - & - & -*t & $-\dagger$ \\
\hline THU_U & - & - & -*t & $-^{\dagger}$ \\
\hline
\end{tabular}

* Partial data coverage due to station establishment that year. ${ }^{\dagger}$ Data may become available after the next maintenance visit. $¥$ Sonic ranger measurement. ${ }^{\$}$ Sonic ranger and stake measurements. ${ }^{* *}$ Sonic ranger and stake measurements for both 2009 and 2010.

ly low winter accumulation and a long period of positive air temperatures, which are both important for net ablation (Tedesco et al. 2011; van As et al. 2012). However, as the energy from solar radiation is the main contributor to the melting of snow and ice, the direct impact on ablation of inter-annual variability of temperature may be small. It was the combination of low winter accumulation and high temperatures, causing low albedo in large sections of the Greenland ice sheet in 2010, that resulted in large net ablation records (Tedesco et al. 2011; van As et al. 2012). The southern (QAS) and south-western (NUK and KAN) parts of Greenland experienced a particularly anomalous ablation season, with ablation totals of up to $3 \mathrm{~m}$ more than in other years. Even more significant was the melt response at stations close to the equilibrium-line altitude (zero net ablation) in the south and west; QAS_U went from a $0.3 \mathrm{~m}$ surface rise in 2009 to a $3.4 \mathrm{~m}$ surface lowering in 2010, and at KAN_M ablation increased from $0.3 \mathrm{~m}$ to $2.6 \mathrm{~m}$ during the same years. Even in normal years, the KAN_U station, which is placed in the accumulation zone, showed a surface lowering due to melt over the year 2010. On the other hand, the northern KPC_U station did not show anomalous ablation, as temperatures did not exceed their normal summer values (Table 2). North-East Greenland did not experience the anomalous circulation pattern that, in particular, southern and western Greenland experienced (Tedesco et al. 2011). Fifteen out of 18 PROMICE stations were successful in obtaining ablation 
totals up until 2011. The remaining three stations (KPC_L, THU_L, and THU_U) did not transmit any data, but data may become available during the next maintenance visit. We obtained 42 interannual ablation totals for all the stations out of 50 possible totals. When disregarding the three stations that did not transmit, the number would be 45 . This gives a success rate of $84 \%$ for all 18 stations, or $93 \%$ when disregarding the 3 non-transmitting stations.

\section{Conclusions}

Ablation totals at low altitudes ( $<500 \mathrm{~m}$ a.s.l.) typically amount to 3-7 $\mathrm{m}$ in the southern part of Greenland, with an ablation total at the more northerly stations of $2-3 \mathrm{~m}$. The ablation totals from the upper stations above $500 \mathrm{~m}$ a.s.l., typically amount to -0.3 to $4 \mathrm{~m}$ in the south (TAS, QAS, NUK, KAN) and -0.1 to $3 \mathrm{~m}$ in the north (KPC, SCO, UPE). The interannual ablation totals show that 2010 was a year with large melt when compared to the other years. The 2010 season showed record-setting ablation totals for the southern (QAS) and south-western stations (NUK and $\mathrm{KAN}$ ), however, a longer time series is needed to quantify the anomalous 2010 ablation totals (van As et al. 2012). The PROMICE station network has successfully obtained ablation totals at the end of 2011 for 15 out 18 stations. The interannual success rate was $84 \%$ for all 18 stations and $93 \%$ if the three non-transmitting stations (KPC_L, THU_L, and THU_U) are omitted.

\section{Acknowledgements}

The Programme for Monitoring of the Greenland Ice Sheet (PROMICE) is funded by the Geological Survey of Denmark and Greenland (GEUS) and the Danish Ministry of Climate, Energy and Building under Danish Cooperation for Environment in the Arctic (DANCEA), and is conducted in collaboration with the National Space Institute (DTU Space) and Asiaq (Greenland Survey). The NUK and KAN stations are (co-)funded by the Greenland Climate Research Centre (GCRC) and the Greenland Analogue project (GAP), respectively.

\section{References}

Ahlstrøm, A.P. \& PROMICE project team 2008: A new programme for monitoring the mass loss of the Greenland ice sheet. Geological Survey of Denmark and Greenland Bulletin 15, 61-64.

Bøggild, C.E., Olesen, O.B., Ahlstrøm, A.P. \& Jørgensen, P. 2004: Automatic glacier ablation measurements using pressure transducers. Journal of Glaciology 50(169), 303-304.

Dahl-Jensen, D. et al. 2009: The Greenland ice sheet in a changing climate: snow, water, ice and permafrost in the Arctic (SWIPA), 115 pp. Oslo: Arctic Monitoring and Assessment Programme (AMAP).

IPCC 2007: Intergovernmental Panel on Climate Change (IPCC) Fourth Assessment Report (AR4), Climate Change 2007. 4 volumes. Cambridge: Cambridge University Press.

Khan, S.A., Wahr, J., Bevis, M., Velicogna, I. \& Kendrick, E. 2010 Spread of ice mass loss into northwest Greenland observed by GRACE and GPS. Geophysical Research Letters 37, L06501, http://dx.doi. org/10.1029/2010GL042460

Rignot, E., Velicogna, I., van den Broeke, M.R., Monaghan, A. \& Lenaerts, J. 2011: Acceleration of the contribution of the Greenland and Antarctic ice sheets to sea level rise. Geophysical Research Letters 38, L05503, http://dx.doi.org/10.1029/2011GL046583

Tedesco, M., Fettweis, X., van den Broeke, M.R., van de Wal, R.S.W., Smeets, C.J.P.P., van de Berg, W.J., Serreze, M.C. \& Box, J.E. 2011: The role of albedo and accumulation in the 2010 melting record in Greenland. Environmental Research Letters 6, 014005, http://dx.doi. org/10.1088/1748-9326/6/1/014005

van As, D., Fausto, R.S. and the PROMICE project team 2011: Programme for Monitoring of the Greenland Ice Sheet (PROMICE): first temperature and ablation records. Geological Survey of Denmark and Greenland Bulletin 23, 73-76.

van As, D., Hubbard, A.L., Hasholt, B., Mikkelsen, A.B., van den Broeke, M.R. \& Fausto, R.S. 2012: Large surface meltwater discharge from the Kangerlussuaq sector of the Greenland ice sheet during the recordwarm year 2010 explained by detailed energy balance observations. The Cryosphere 6, 199-209.

van den Broeke, M., Bamber, J., Ettema, J., Rignot, E., Schrama, E., van de Berg, W.J., van Meijgaard, E., Velicogna, I. \& Wouters, B. 2009: Partitioning recent Greenland mass loss. Science 326, 984-986.

Velicogna, I. 2009: Increasing rates of ice mass loss from the Greenland and Antarctic ice sheets revealed by GRACE. Geophysical Research Letters 36, L19503, http://dx.doi.org/10.1029/2009GL040222

\footnotetext{
Authors' address

Geological Survey of Denmark and Greenland, Øster Voldgade 10,DK-1350 Copenhagen K, Denmark. E-mail: rsf@geus.dk
} 